\title{
Load Dependency of Left Ventricular Diastolic Dysfunction Parameters
}

\author{
Mihaela Opris, Dan Octavian Nistor, Corina Roxana Cimpean, Voichita Ileana Sirbu
}

Department of Internal Medicine V, University of Medicine and Pharmacy of Targu Mures, Targu Mures, Romania

To the Editor,

We read the article of Sağ et al. (1) about the hemodialysisinduced modifications of the left ventricular diastolic dysfunction parameters with great interest. The study of patients before and after hemodialysis is a valuable tool in determining the load dependency of different echocardiographic parameters. However, studies in this field have produced variable results.

We have studied 26 adult patients ( 21 men, mean age $43 \pm 12$ years) with end-stage renal disease and without previous known heart disease who underwent echocardiography before and after hemodialysis sessions over the course of one year, with a mean fluid removal of $1830 \pm 580 \mathrm{~mL} / \mathrm{session}$. Regarding the parameters of diastolic dysfunction studied, we did not find a significant difference in the pre- and post-hemodialysis ratio between the early diastolic mitral annulus velocity (Em) and the late atrial mitral annulus velocity (Am), measured by tissue Doppler and averaged for the septal, lateral, anterior and posterior annulus. Moreover, observing the pulsed Doppler pulmonary vein flow, the velocity of the systolic (S) wave and the ratio between the systolic and diastolic (D) waves did not change significantly after hemodialysis, although some variability was observed in the velocity of the $\mathrm{D}$ wave. This finding differs from the study of Sağ et al. (1); the results are presented in Table 1.

Controversial data exist about the volume load influence of diastolic dysfunction parameters. Drighil et al. (2) found the tissue Doppler Em/Am ratio to be load-dependent, but only after large fluid volume reductions following hemodialysis, and did not find any preload-independent parameters. The study of Abid et al. (3) found the pulmonary vein flow systolic velocity and also the diastolic intraventricular flow propagation velocity to be load-independent parameters. We must note that most of the studies in the field suffer from a small population size and, perhaps more importantly, vary greatly in fluid quantity
TABLE 1. Echocardiographic diastolic dysfunction parameters pre- and post-hemodialysis $(\operatorname{mean} \pm \mathrm{SD})$

\begin{tabular}{lccc}
\hline Echocardiographic parameters & $\begin{array}{c}\text { Before } \\
\text { hemodialyis }\end{array}$ & $\begin{array}{c}\text { After } \\
\text { hemodialysis }\end{array}$ & $\begin{array}{c}\mathrm{p} \\
\text { value }\end{array}$ \\
\hline Em/Am septal & $0.82 \pm 0.28$ & $0.79 \pm 0.34$ & 0.35 \\
Em/Am lateral & $0.87 \pm 0.29$ & $0.82 \pm 0.36$ & 0.09 \\
Em/Am anterior & $0.86 \pm 0.33$ & $0.81 \pm 0.31$ & 0.12 \\
Em/Am posterior & $0.85 \pm 0.30$ & $0.82 \pm 0.33$ & 0.28 \\
Em/Am & $0.85 \pm 0.32$ & $0.81 \pm 0.29$ & 0.24 \\
$\mathrm{~S}(\mathrm{~cm} / \mathrm{s})$ & $65 \pm 12$ & $63 \pm 10$ & 0.31 \\
$\mathrm{D}(\mathrm{cm} / \mathrm{s})$ & $63 \pm 14$ & $56 \pm 11$ & 0.03 \\
$\mathrm{~S} / \mathrm{D}$ & $1.05 \pm 0.31$ & $1.12 \pm 0.36$ & 0.18 \\
\hline
\end{tabular}

Em: early diastolic mitral annulus velocity; Am: diastolic late atrial mitral annulus velocity; S: pulmonary vein flow systolic wave velocity; D: pulmonary vein flow diastolic wave velocity

loss by hemodialysis, which is a variable that significantly influences the echocardiographic measurements.

Further investigation of these parameters is warranted, given the fact that diastolic dysfunction is a predictor of mortality, especially in chronic kidney disease patients (4). In this regard, a larger study or perhaps a meta-analysis could provide better understanding of the subject.

Ethics Committee Approval: Ethics Committee approval was received for this study from the ethics committee of the University of Medicine and Pharmacy of Targu Mures.

Informed Consent: Writen informed consent was obtained from the patients who participated in this case.

Peer-review: Externally peer-reviewed.

Author contributions: Concept - M.O., D.O.N.; Design - M.O., D.O.N.; Supervision - C.R.C.; Resource - M.O., V.I.S.; Materials - 
V.I.S.; Data Collection \&/or Processing - M.O., D.O.N., V.I.S.; Analysis \&/or Interpretation - C.R.C.; Literature Search - D.O.N., V.I.S.; Writing - C.R.C., D.O.N.; Critical Reviews - M.O., D.O.N., C.R.C., V.I.S.

Conflict of Interest: No conflict of interest was declared by the authors.

Financial Disclosure: The authors declared that this study has received no financial support.

\section{REFERENCES}

1. Sağ S, Yeşilbursa D, Yıldız A, Dilek K, Sentürk T, Serdar OA, et al. Acute haemodyalisis-induced changes in tissue Doppler echocardiography parameters. Balkan Med J 2014;31:239-43.

2. Drighil A, Madias JE, Mathewson JW, El Mosalami H, El Badaoui N, Ramdani B, et al. Haemodialysis: effects of acute decrease in preload on tissue Doppler imaging indices of systolic and diastolic function on the left and right ventricles. Eur $J$ Echocardiogr 2008;9:530-5.

3. Abid L, Rekik H, Jarraya F, Kharrat I, Hachicha J, Kammoun S. Acute hemodialysis effects on Doppler echocardiographic indices. Saudi J Kidney Dis Transpl 2014;25:756-61.

4. Farshid A, Pathak R, Shadbolt B, Arnolda L, Talaulikar G. BMC Nephrol 2013;14:280.

\section{AUTHORS' REPLY}

Saim Sağ ${ }^{1}$, Abdülmecit Y1ldız², Dilek Yeşilbursa ${ }^{1}$

${ }^{1}$ Department of Cardiology, Uludağ University School of Medicine, Bursa, Turkey

${ }^{2}$ Department of Nephrology, Uludağ University School of Medicine, Bursa, Turkey

\section{Dear Editor,}

We would like to thank the authors for their comments and contributions about our original research entitled "Acute hemodialysis-induced changes in tissue Doppler echocardiography parameters" that was published in the September 2014 issue of the Balkan Medical Journal (1). I would like to provide some methodological explanations to clarify the criticisms mentioned in their letter.

In our study, we have studied 58 adult patients $(30$ males and 28 females; mean age $41.6 \pm 13.1$ years and a mean hemodialysisduration of $73.7 \pm 51.8$ months) with history of endstage renal disease (ESRD) in the absence of documented athero- sclerosis, or systemic pathologies (including malignancy, active infection, or inflammation) and without previous known heart disease who underwent echocardiography before and after hemodialysis with a mean fluid removal of $2863 \pm 602 \mathrm{~mL} / \mathrm{session}$.

In our study, we showed that the $\mathrm{Em} / \mathrm{Am}$ ratio was a relatively load-independent index of diastolic function. This result is similar to that showed in the authors' letter. Unlike to their findings, we showed that a single hemodialysis session lead to acute deterioration in diastolic parameters, as examined by conventional Doppler echocardiography. In our study, both pulmonary inflow systolic (S) and diastolic (D) velocities declined after hemodialysis session. Because D velocity decreased more than $\mathrm{S}$ velocity, the ratio of S/D markedly elevated as well. These discrepancies could be related to differences in the study population size (26 patients vs. 58 patients) and ultrafiltration volume (1830 Ml vs. $2863 \mathrm{~mL}$ ). Indeed, in the Table 1 given by the authors both $\mathrm{S}$ and $\mathrm{D}$ velocities mildly and non-significantly deteriorated after hemodialysis treatment. If their sample size had been larger, their significance levels could be similar to our results.

In conclusion, controversial data exists about the volume independent diastolic echocardiographic parameters in patients with ESRD (2-5). Therefore, larger randomized controlled trials or meta-analyses are necessary in this study population.

Address for Correspondence: Saim Sağ, Department of Cardiology, Uludağ University Faculty of Medicine, Bursa, Turkey

Phone: +90 224 2951618, +902242951640ｅ-mail: saimsag@gmail.com

\section{REFERENCES}

1. Sağ S, Yeşilbursa D, Yıldız A, Dilek K, Sentürk T, Serdar OA, et al. Acute haemodyalisis-induced changes in tissue Doppler echocardiography parameters. Balkan Med J 2014;31:239-43. [CrossRef]

2. Dubin RF, Beatty AL, Teerlink JR, Schiller NB, Alokozai D, Johansen KL. Associations of tissue Doppler imaging with NT-proBNP and hs-TnT: a pilot study in end-stage renal disease. Echocardiography 2014;31:1205-12. [CrossRef]

3. Assa S, Hummel YM, Voors AA, Kuipers J, Groen H, de Jong PE, et al. Changes in left ventricular diastolic function during hemodialysis sessions. Am J Kidney Dis 2013;62:549-56. [CrossRef]

4. Akkaya M, Erdoğan E, Sağ S, Arı H, Türker Y, Yılmaz M. The effect of hemodialysis on right ventricular functions in patients with end-stage renal failure. Anadolu Kardiyol Derg 2012;12:5-10. [CrossRef]

5. Abid L, Rekik H, Jarraya F, Kharrat I, Hachicha J, Kammoun S. Acute hemodialysis effects on doppler echocardiographic indices. Saudi J Kidney Dis Transpl 2014;25:756-61. [CrossRef] 